\begin{tabular}{|c|c|c|}
\hline & \multicolumn{2}{|c|}{$\begin{array}{c}\text { JOURNAL OF ACADEMIC PERSPECTIVE ON } \\
\text { SOCIAL STUDIES (JAPSS) }\end{array}$} \\
\hline & SOSYAL ÇALIŞMA & $\begin{array}{l}\text { ÜZERINE AKADEMIK PERSPEKTIF } \\
\text { DERGISİ }\end{array}$ \\
\hline E-ISSN: 2667-5889 & https://dergipark.org.tr/tr/pub/japss & Paper Type: Research Paper, Makale Türü:Araştırma \\
\hline Sayl:1, Nisan 2021 & Issue:1, April 2021 & $\begin{array}{l}\text { Received Date / Gelis Tarihi: } 31 / 03 / 2021 \\
\text { Accepted Date / Kabul Tarihi: 03/04/2021 }\end{array}$ \\
\hline
\end{tabular}

\title{
THE MODERATOR ROLE OF STRATEGIC PLANNING PERFORMANCE IN THE EFFECT OF MANAGERS AUTONOMY ON STRATEGIC CONTROL: A RESEARCH IN KONYA ORGANIZED INDUSTRIAL ZONE
}

Atıf/ to Cite (APA): Erdem, A.T. (2021). The Moderator Role Of Strategic Planning Performance in The Effect of Managers Autonomy on Strategic Control: A Research in Konya Organized Industrial Zone, Journal of Academic Perspective on Social Studies, (1), Ahmet Tuncay ERDEM ${ }^{1}$ $72-85$

DOI: https://doi.org/ 10.35344/japss.907623

\begin{abstract}
This study's main purpose is to determine whether "strategic planning performance" has a moderator function in the effect of manager autonomy, which is a positive manager behavior, on strategic control. In this study, whether strategic planning performance has a moderator role in the effect of manager autonomy on strategic control is tried to be answered. According to the quantitative research method and relational scanning model, the research is structured, one of the general scanning models. The data required to test the research hypotheses were collected according to the convenience sampling technique, and statistical analyzes were made on the collected data using AMOS and SPSS programs. According to the findings obtained from the research data analysis, it was determined that managers' autonomy behaviors have positive effects on strategic control, and strategic planning performance has a significant effect on strategic control. On the other hand, it has been determined that strategic planning performance does not have a moderator function in the effect of manager autonomy on strategic control. In organizations where manager autonomy is high, strategic control also increases, and at the same time, strategic planning performance strengthens strategic control. On the other hand, it is seen that strategic planning performance does not affect the interaction between manager autonomy and strategic control. These results show that managers who can make autonomous decisions can ensure stability and control in the organization, while control also improves performance.
\end{abstract}

Keywords:Strategic planning performance, Managers autonomy, Emotional leadership.

\section{INTRODUCTION}

Nowadays, it is known that managers have great roles in terms of sustaining their activities. To create an effective and efficient organizational structure, managers are expected to have the initiative in their decisions. Besides, managers' freedom of decision-making ineffective organizational activities will enable them to establish a more clear and stable organizational structure. In this context, organization managers, who are held responsible for the organization's success and its activities, can be successful by providing strategic control. On the other hand, for organizations to be successful, their strategic performance is expected to be stable and high.

Although autonomy provides managers with more room for flexibility in terms of strategic control, it may cause top management to have more control over the actions of managers. (Saydam, 2020: 2). Autonomy defines the independence given to teams or managers within the organization to develop suggestions or new ideas and bring them into the competitive

\footnotetext{
${ }^{1}$ Asst. Prof. Dr., Bolu Abant İzzet Baysal University, Faculty of Communication, ahmeterdem@ibu.edu.tr, ORCID ID: https://orcid.org/0000-0003-4573-8415
} 
environment (Hughes and Morgan, 2007). Managers who can make autonomous decisions will at some point have management strategies and control in management. According to Karakaya and Akbulut (2013: 197), strategic control is related to the determination of the previous period's problems and the efforts to solve them in the process of preparing the strategic plans of senior managers. Strategic control is focused on internal and external environmental factors that are often beyond business managers' control. In this context, the organization is expected to have strategic control to be effective in the external environment that it has difficulty changing the manager and the internal environment that it can control.

It is widely discussed in the literature that organizational factors affect the control and performance provided in the organization (Shrivastava and Grant, 1985). Managers are affected by the level of autonomy they have to use resources effectively and the degree of control they are subject to. On the other hand, with the developing information technologies and communication around the world, the struggle for sustainable economic development and the increase in business competition directs organizations' attention to strategic control, which is increasingly important (Kuye and Oghojafor, 2011). It is important for managers to be autonomous in resource use and to fulfill organizational goals by using these resources. Managers will gain strategic control by feeling independent in the organization and acting autonomously in using resources. On the other hand, achieving control by acting autonomously in the organization may increase performance.

Although there are various studies on manager autonomy, strategic control, and strategic planning performance (Bowman and Asch, 1992; Bryson, 2004; Elbanna, 2013; 2016; Karacaoğlu and Saydam, 2020; Saydam, 2020), these three variables are stated in this research model. There is no such research. Combining in the same equation that strategic planning performance cannot function as a moderator variable under the effect of strategic control of manager autonomy, it can be argued that this research will contribute to the original, important and literature. In the research, whether strategic planning performance has a moderator role in manager autonomy's strategic control effect has been tried to be answered.

\section{CONCEPTUAL FRAMEWORK}

\subsection{Manager Autonomy}

Autonomy defines the authority and independence given to teams or managers within the organization to continue these proposals, developed to develop new ideas or suggestions until they are completed (Hughes and Morgan, 2007). Autonomy is a way of doing business that includes the independence, initiative, and freedom of a person that is allowed or required in daily business activities (Stamps and Piedmont, 1986). Drafke and Kossen (1998) express autonomy as an individual's freedom to perform duties and control work. On the other hand, autonomy is environmental dominance defined as the individual's ability to adapt himself to the environment or the environment to regulate his environment and meet his psychological and physical needs (Keyes et al., 2002).

Manager autonomy can be specified as the independent decision-making ability of the manager. Essentially, manager autonomy starts with the autonomy of employees. Autonomy represents a decentralized organizational context or a decision structure in which managers can act without prior approval by top management and when the manager is not even aware of it (Andersen and Nielsen, 2009). In other words, manager autonomy starts with the extent to which mid-level managers can act and make decisions without senior management's approval. With autonomy, 
middle managers find strength in themselves to solve the organizational problems they encounter. Solutions for organizational problems are achieved by taking steps towards autonomy and authority expansion. With professional managers' empowerment in organizations, autonomy will also develop and contribute to organizational problems with autonomy (Bell, 1976). Management autonomy can be designed as a multidimensional concept that points to discretion in decisionmaking and policy implementation in personnel or financial matters (Bach, 2010). Besides, although autonomy provides managers with more flexibility to act, strategic control also provides tools for tighter senior management control over their actions (Elbanna, 2016: 211).

\subsection{Strategic Control}

Strategic control is an understanding developed to help senior managers cope with changes and other problems that arise after a strategic plan is prepared (Edwards and LaFief, 2004). Merchant (1988) defines strategic control as ensuring that the adopted strategies are properly implemented and determine whether the applied strategy is valid. Besides, control strategies are also concerned with the fundamental question of whether resources are used to bring the organization closer to its goals and what to do if resources are not used correctly (Miller, 1996). Strategic control is focused on internal and external environmental factors that are often beyond business managers' control. For this reason, these factors should be taken under control as much as possible for strategic control to be beneficial. In this sense, it helps senior managers in strategic control, control environmental variables, and increase corporate performance (Kuye and Oghojafor, 2011). Strategic control is the set of activities aimed at evaluating and controlling the results of effective strategies and implementation developed to achieve the predetermined or revised goals according to the situation during the implementation process (Rodoplu, 2004: 254). Strategic control, which is the last stage of the strategic management process, is an important function used in determining the success of strategic implementations and related to the monitoring and control process of activities (Abas and Yaacob, 2006: 162).

In the control phase, which is turned into a forward feeding according to the contemporary strategic control approach, those who control important changes and trends determine the strategies and objectives that need to change and ensure that measures are taken promptly. The last stage of the strategic management process is strategic control. Strategic control is required to achieve potential success. Strategic control is looking at whether top managers' strategic choices and their decisions regarding strategies are realized to achieve the general goals (Karacaoğlu and Saydam, 2020: 617).

\subsection{Strategic Planning Performance}

Strategic management, which started to be used in management in the second half of the 20th century, is making and placing strategic decisions (Bowman and Asch, 1992: 17). Strategy means "to refer, direct, send, carry and carry." (Acar, 2007: 6). The concept of strategy emerges that has been used for centuries and is more dominant in the military field (Sütçü, 2008: 9). Strategic management; It is the planning of analysis, evaluation, selection efforts, and research required for planning strategies. These planned actions are to continue by taking all kinds of motivation within the organization and implementing structural measures to implement the strategies. After these stages, it can also be expressed as the totality of the processes that involve checking the strategies in terms of compliance with the objectives before implementing them, which concern the organization's top managers' activities (Gümüş, 1995: 315; Adigüzel, 2020). 
Since strategic planning ability is a skill that enables the firm to create strategic plans by considering the external environment, the firm should be informed as much as possible about the external environment. The company's external environmental knowledge can provide both better resolution of market opportunities and easier recognition of possible threats. Besides, strengths and weaknesses can be determined more objectively with the acquired external environmental knowledge (Yam et al., 2004; Khan and Khalique, 2014; AlQershi, 2021). The main purpose of organizational performance management is to present the systematic controls involved in management processes with managerial discretion, decision-making, and action tools, and to regulate and guide the activities of the organization or the subsystems of the organization to reach the agreed goals (Hicks and Gullett, 1981: 54). Strategic planning is a disciplined study that "shapes what an organization is, what it does and why it does it, and produces basic decisions and actions that guide this process (Bryson, 2004: 6). Planning is one of the management functions, and it is expressed as determining the organization's goals and determining the steps to be taken in line with these goals with a rational approach (Weihrich and Koontz, 2005). On the other hand, according to another definition, strategic planning determines the mission, main purpose, strategy, and policies that direct the acquisition and distribution of resources necessary to achieve the organization's goals (Pearce and David, 1987: 109).

Developing technology and changing social structure necessitated a radical change and transformation of management mechanisms (Çukurçayır and Eroğlu, 2005: 129). Performance is the ability of an enterprise to reach its goals by using its resources effectively and efficiently. It is the performance of works by the organizations' standards and the fulfillment and achievement of the expected goals following the conditions (Gül, 2013: 5). Performance, showing behaviors by predetermined standards; degree of approach to expected goals (Ekber and Mirzayeva, 2016: 123). Strategic planning is also expressed as drawing a road map in line with the organization's objectives. Its difference from planning is that the activities, current situations, and possible changes of external environmental elements are taken into account in determining this road map (Ülgen and Mirze, 2013). Considering the public's financial and administrative problems, it becomes more important for public institutions to carry out their activities in a planned manner. It is deemed necessary for public institutions to take the initiative and actively participate in producing planned services, basing the determining policies on concrete work programs and budgets, and effectively monitoring the implementation. "Strategic planning" comes to the fore as a basic tool in executing these activities by organizations (Hastürk and Kontrolörü, 2006: 6). Strategic planning performance needs to produce a product with good performance through an appropriate processor to put it into consumers' use and increase strategic planning performance. It is recommended to use the strategic planning indexes of organizations to determine strategic planning performance (Phillips and Moutinho, 2000; Phillips, 2003).

\subsection{Manager Autonomy, Strategic Planning Performance and Strategic Control Relations}

The strategic management literature states that strategic control practices are important to monitor strategic developments in the organization and ensure the implementation of targeted strategic plans (Goold and Quinn, 1990). Innovation and uncertainty in the strategic planning process structure direct strategic planning to encounter political influence attempts by organizational actors (Ferris et al., 1989). The general problem of strategic planning is implementation, so strategic planning literature focuses on strategic planning effectiveness. Many empirical studies in the literature confirm the strategic plan's supportive role in creating better long-term competitive positions and better organizational performances (Saydam, 2020: 39). 
Strategic control is cited among the core activities of strategic management issues, and the importance attributed to this activity is less than other activities such as the formulation of strategic plans (Goold and Quinn, 1990). Strategic control; helps to direct the behaviors towards organizational interests instead of thinking about the values, systems, rules, and other activities adopted by management and practices and employees' interests (Otley et al., 1995). Organizations that take strategic control measure their strategic plan performances by setting strategic goals as a standard. It is also stated as a process in which feedback is given about unwanted differences to compare this performance with standards. Although it is stated that strategic monitoring or strategic control is among the basic activities of strategic management, it is seen that the emphasis on this activity is less than other activities such as the formulation of strategic plans (Berry et al., 2009; Nixon and Burns, 2012; Elbanna, 2013). On the other hand, autonomy, defined as the freedom of an individual to fulfill duties and control the work (Drafke and Kossen, 1998), contributes significantly to both performance and strategic control in the organization. Here, low control in terms of limited autonomy, combined with high demands, brings negative risk (Karasek, 1990) and low performance (Bakker et al., 2004). In this context, the strategic control of managers who can make autonomous decisions will increase, and accordingly, strategic planning performance will be positively affected. The strategic management literature states that the strategic control system is important to monitor strategic progress and ensure strategic plans (Goold and Quinn, 1990). The uncertainty and innovation inherent in strategic planning processes increase the likelihood that strategic planning will encounter organizational actors' political influence attempts (Ferris et al., 1989). The general problem of strategic planning is implementation, so strategic planning literature focuses on strategic planning effectiveness. Many empirical studies in the literature confirm the strategic plan's supportive role in creating better long-term competitive positions and better organizational performances (Saydam, 2020: 39).

The research model regarding strategic control variables, strategic planning performance, and manager autonomy within the research scope is shown in Figure 1.

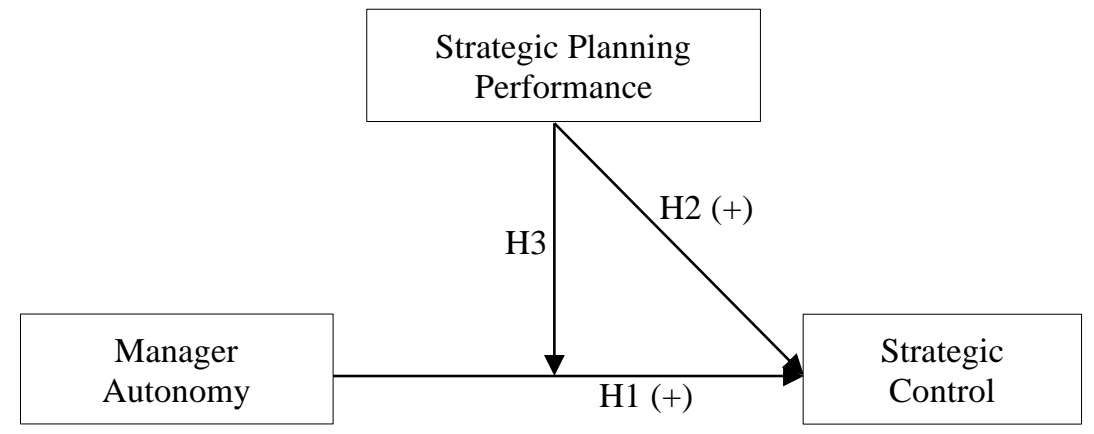

Figure 1. Research Model

According to the research model in Figure 1, strategic control (dependent variable), strategic planning performance (moderator variable), and manager autonomy (independent variable) are constructed. In line with the research model, the following hypotheses have been developed;

H1: Manager autonomy has a positive effect on strategic control.

$\mathrm{H} 2$ : Strategic planning performance has a positive effect on strategic control. 
H3: Strategic planning performance plays a moderator role in the effect of manager autonomy on strategic control.

\section{METHOD}

In scientific research, a research model and hypotheses should be developed systematically to determine the events and phenomena in the universe, and the hypotheses that have been constructed should be tested with a scientific research method (Tutar and Erdem, 2020: 71). In this framework, the research's scientific method as a systematic process has been determined as quantitative research.

The design of scientific research serves as a guide to answer the research question determined within the research scope and test the determined hypotheses (Tutar and Erdem, 2020: 77). Research patterned towards the relational scanning model, based on the general scanning model, has been designed in this context. Research models and hypotheses were tested by quantitative research method by subjecting the obtained data to analysis, and this analysis was carried out by following a systematic process.

\subsection{Research Sample}

The universe of the study consists of senior executives operating in the manufacturing industry of Konya. In the study, Konya Büsan Sanayii was chosen as the sample due to time and financial constraints. In this direction, a total of 325 business executives operating in the Büsan Industry constitute the research sample. 213 usable questionnaires were obtained from the relevant enterprises by the convenience sampling method. The reason for choosing the random sampling method in the research is that the participants representing a part of the universe can be selected with an equal chance of being selected (Tutar and Erdem, 2020: 246).

\subsection{Data Collection Tool}

In the research, Andersen and Nielsen (2009) developed the manager autonomy scale and consists of three items. Titus et al. The three-item strategic control scale developed by (2010) and the sixitem strategic planning performance scale, Saydam (2020), were used. Research data were collected from related businesses between 10.09.2019 and 17.11.2019.

\subsection{Validity and Reliability}

Within the scope of the research, first of all, reliability analyzes of the scales were made. It was determined that $\alpha=0.847$ for the manager autonomy scale, $\alpha=0.852$ for the strategic control scale, and $\alpha=0.894$ for the strategic planning performance perception scale. According to these results, it is seen that the scales are reliable.

Confirmatory factor analysis (CFA) was applied to the measurement model to determine the reliability and validity of the strategic planning performance scale, manager autonomy, and strategic control scales (Figure 2). 


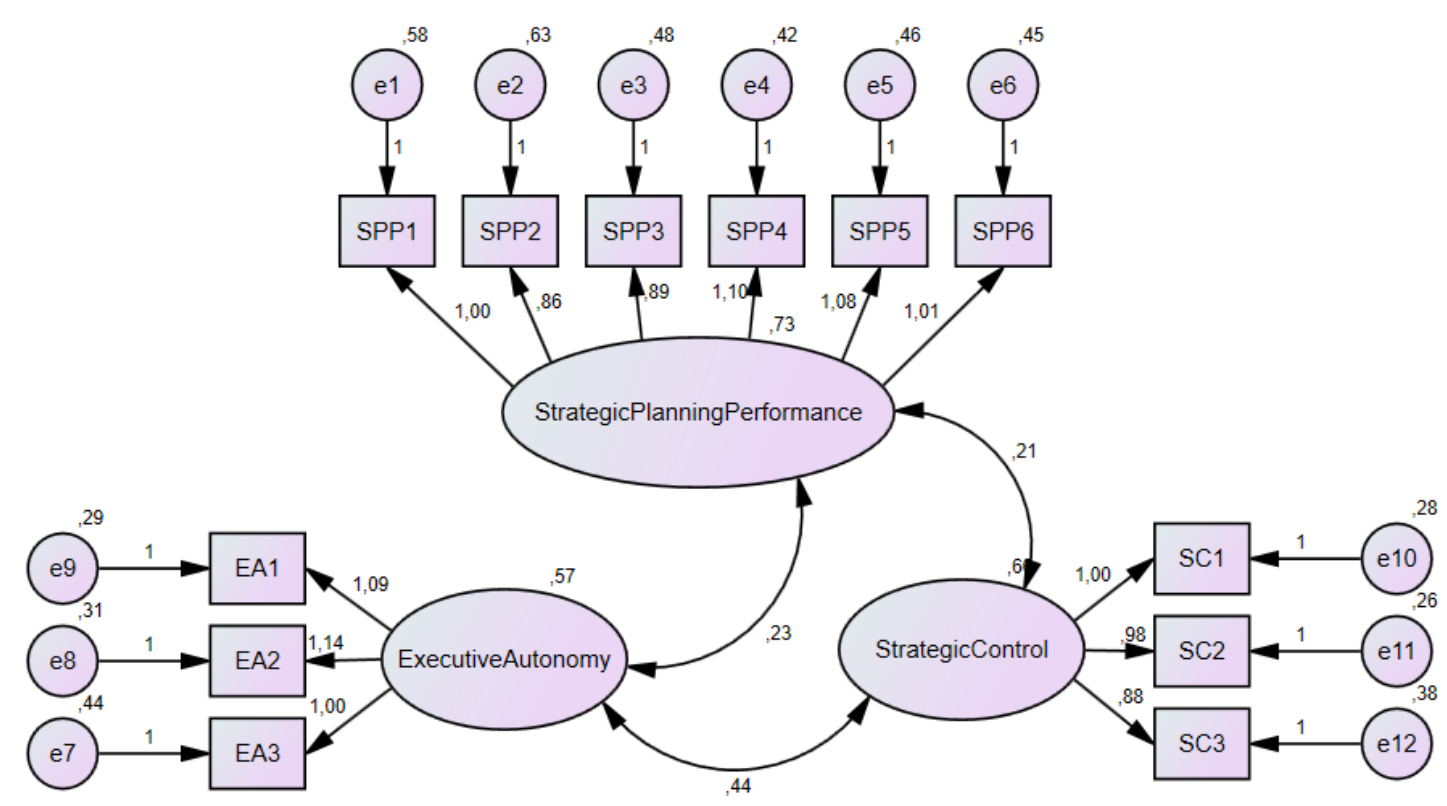

Goodness of Fit Values of the Model: $\chi 2 / \mathrm{DF}=2,567 ; \mathrm{GFI}=.940 \mathrm{NFI}=.944 \mathrm{CFI}=.965$

TLI=.954 RMSEA $=.067$

Figure 2: Confirmatory Factor Analysis Diagram for the Model

After the confirmatory factor analysis, the model was tested again. Then, a comparison was made between the research model and the single factor model by applying a single-factor model. The values obtained are shown in Table 1.

Table 1: Model-Data Fit Values

\begin{tabular}{|c|c|c|c|c|c|c|c|c|c|}
\hline & $X^{2}$ & $\Delta X^{2}$ & $\mathrm{DF}$ & $\mathrm{X}^{2} / \mathrm{DF}$ & GFI & NFI & CFI & TLI & RMSEA \\
\hline $\begin{array}{l}\text { Single-factor } \\
\text { model }\end{array}$ & 1036.73 & - & 54 & 19.19 & .566 & .555 & .565 & .469 & .229 \\
\hline Research & & & & & & & & & \\
\hline $\begin{array}{l}\text { Model } \\
\mathrm{p}<0.01\end{array}$ & 130.90 & 905.83 & 51 & 2.56 & .940 & .944 & .965 & .954 & .067 \\
\hline
\end{tabular}

According to the confirmatory factor analysis result in Table 1, the research data were tested by distributing them to 3 measurement models. Good fit validity measures are shown with the results obtained with the fit indexes of RMSEA, GFI, NFI, CFI, TLI, and $\chi^{2}$ / DF for the model. In Table 1 , it was determined that $\chi 2$ value was significant according to the 3 -factor model ( $\mathrm{p}<0.01)$. In addition, it is seen that the model is compatible in terms of validity since the $\chi 2$ / DF value $(2,563)$ is below 5. Since the fit indices of the research models are GFI $=0.940, \mathrm{NFI}=0.944$, TLI $=0.954$, $\mathrm{CFI}=0.965$ and RMSEA $=0.067$, it is seen that the model is compatible. In addition, in the same table (Table 1), Chi-Square Test was applied to $\chi^{2}$ values to determine the significant difference between the single-factor model and the three-factor model of the significant research difference between the two values. According to these results, it is seen that there is no common method deviation in the study (MacKenzie and Podsakoff, 2012). 
Table 2. Standard Deviation, Mean, and Correlation Values of the Variables

\begin{tabular}{lccccccc}
\hline & Mean & SD & CR(t) & AVE & 1 & 2 & 3 \\
\hline Manager Autonomy & 3,78 & 0,879 & 0,849 & 0,653 & - & & \\
Strategic Planning Per & 4,05 & 0,841 & 0,895 & 0,588 & $0,618^{* *}$ & - & \\
Strategic Control & 3,84 & 0,899 & 0,854 & 0,661 & $0,319^{* *}$ & $0,271^{* *}$ & - \\
\hline
\end{tabular}

Note: SD, standard deviation; $* 0.05 * * 0.01 * * *$ Significant at 0.001 level (bi-directional)

To determine whether the variables provide compatibility and measurement with the research model, validity, discriminant validity and convergent techniques were used. Hair et al. (2006) believe that the scale items' factor loads are higher than 0.5 in a study that shows that the research model meets the measurement criterion. In this context, the standardized factor loadings of the items belonging to the research expression scales are above the value of 0.5. Also, the t values at the parametric valuation point of the factor loads vary between 12.50 and 16.83 (Figure 2). According to these values, the research model is meaningful (Hair et al., 2006).

The fact that the average explained variance (AVE) value in the research model's analysis is higher than 0.5 is shown as proof of convergent validity (Fornell and Larcker, 1981). In this context, it is seen that the AVE values of all three scales are higher than 0.5. For discriminant validity, the correlation values between the research scales should be less than 0.80 (Kline, 2014). According to Table 2, the structure reliability (CR) obtained from the relevant scales is expressed as proof of the reliability of the measurement results if both reliability levels are higher than 0.70 (Fornell and Larcker, 1981; Hair et al., 2006). There is a positive relationship between manager autonomy and strategic planning performance $(\mathrm{r}=0.618, \mathrm{p}<.001)$. There is a positive correlation between manager autonomy and strategic control $(\mathrm{r}=0.319, \mathrm{p}<.001)$. There is a positive correlation between strategic planning performance and strategic control $(r=0.271, \mathrm{p}<.001)$. According to the correlation values, it is seen that there are significant relationships between variables.

\section{METHOD}

\subsection{Demographic Findings}

The participants' demographic information, such as gender, education level, age, and seniority, are explained in Table 3.

Table 3. Distribution of Demographic Data Regarding the People Participating in the Study

\begin{tabular}{lrrrrr}
\hline Gender & Frequency $(\mathbf{n})$ & Percent $(\boldsymbol{\%})$ & Marital Status & Frequency $(\mathbf{n})$ & Percent (\%) \\
\hline Female & 59 & 29,7 & Single & 103 & 42,6 \\
\hline Male & 154 & 70,3 & Married & 110 & 57,4 \\
\hline Total & $\mathbf{2 1 3}$ & $\mathbf{1 0 0 , 0 0}$ & Total & $\mathbf{2 1 3}$ & $\mathbf{1 0 0 , 0 0}$ \\
\hline Age & Frequency (n) & Percent $(\boldsymbol{\%})$ & Education Status & Frequency (n) & Percent $(\boldsymbol{\%})$ \\
\hline $26-35$ & 45 & 21,1 & High School & 75 & 35,2 \\
\hline $36-45$ & 72 & 33,8 & License & 98 & 46,0 \\
\hline $46-55$ & 30 & 14,1 & Master & 40 & 18,8 \\
\hline $56-$ above & 66 & 31,0 & & & \\
\hline Total & $\mathbf{2 1 3}$ & $\mathbf{1 0 0 , 0 0}$ & Total & $\mathbf{2 1 3}$ & $\mathbf{1 0 0 , 0 0}$ \\
\hline
\end{tabular}

In Table 3, 29.7\% of the participants are women, and 70.3\% are men. Considering the participants' marital status, it was determined that $57.4 \%$ were married and $42.6 \%$ were single. When the 
distribution by education level is examined, it is seen that $35.2 \%$ of the participants are high school graduates, $46 \%$ are undergraduate, and $18.8 \%$ are graduate. According to the age range, it is seen that $33.8 \%$ of the participants are composed of a personnel who are concentrated in the $36-45$ age range.

\subsection{Testing Research Hypotheses}

For testing the hypotheses, the structural equation model was applied to the research data. In Table 4 and Figure 3, the moderator effect results from the structural equation model analysis are given.

Table 4: Supported and Unsupported Hypotheses According to the Structural Equation Model

\begin{tabular}{lllrcc}
\hline Independent Variables & Dependent Variables & $\beta$ & $\mathrm{t}$ & $\mathrm{SE}$ & $\mathrm{p}$ \\
\hline Manager autonomy & Strategic Control & .602 & 14.139 & .040 & $* * *$ \\
Strategic Planning Performance & Strategic Control & .086 & 2.032 & .039 & .042
\end{tabular}

\section{Moderate Effect}

$\begin{array}{llllll}\text { (Manager autonomy * Strategic } & \text { Strategic Control } & .017 & .391 & .030 & .696\end{array}$ Planning Performance)

Note: SE, standard error; $* 0.05 * * 0.01 * * *$ Significant at 0.001 level (bi-directional)

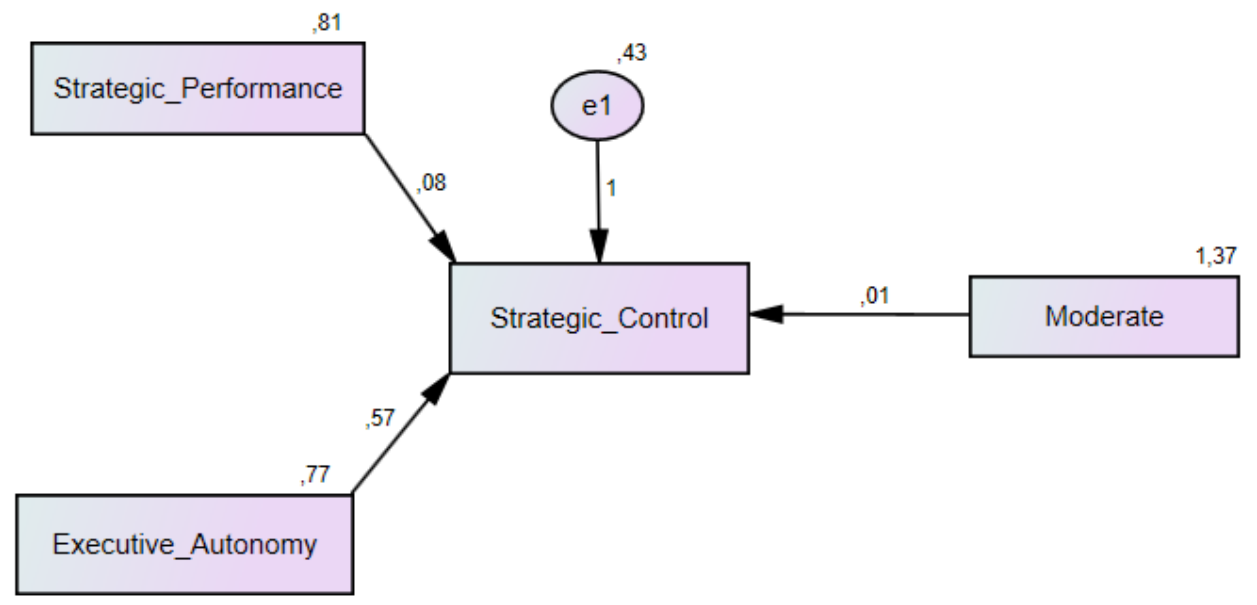

Figure 3: Structural Equation Model

The structural equation model has been used to test the predicted hypotheses. It has been shown in Table 4 and Figure 3, manager autonomy has a positive and significant effect on strategic control $(\beta=0.602, p<0.001)$. The H1 hypothesis is supported. Strategic planning performance has a significant positive effect on strategic control $(\beta=0.086, p=0.042<0.05)$. The H2 hypothesis is supported.

To determine the moderator variable's role within the research scope, whether strategic planning performance has a moderator role in the effect of manager autonomy on strategic control has been tested. According to analysis results, it has been seen that strategic planning performance had no moderator role $(\mathrm{p}=0.696>0.001)$. The $\mathrm{H} 3$ hypothesis is not supported. In order to express the moderator effect, a regression curves plot was created. The graph shows that the curves between variables do not intersect (Figure 4). 


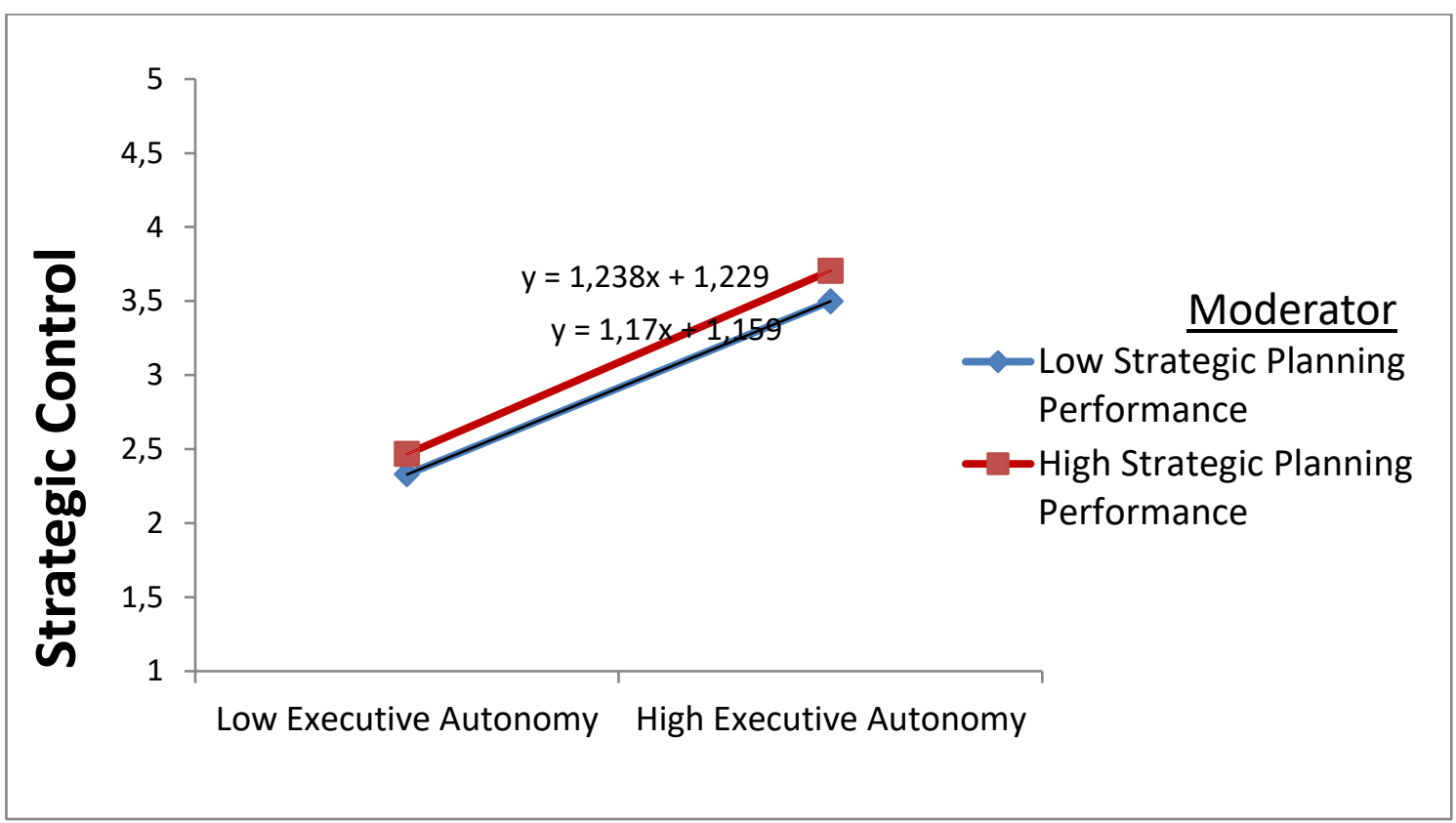

Figure 4: Moderator analysis regression curves

\section{CONCLUSION}

This study deals with the "moderator" role of strategic planning performance in the effect of manager autonomy on strategic control. It is understood that the positive decision-making conditions provided by "manager autonomy" occur, and these conditions strengthen their strategic control behaviors. On the other hand, considering that managers' strategic planning performances strengthen "strategic control" and therefore strategic planning performance will have a moderator function in the interaction of manager autonomy and strategic control, a research model has been set up for the moderator role of strategic planning performance. In this context, it was determined that strategic planning performance does not have a moderator role. According to these findings, it has been determined that strategic control is effective for the manager to have autonomy in the decision-making process. Nevertheless, suppose the autonomous behavior of the manager in decision making affects the strategic control. In that case, it is expected that the strategic planning performance has an increasing effect on this effect, but the absence of this effect can be seen as an unexpected result in the study.

In the research on the subject, the manager's inability to make decisions and control himself can cause organizations' important problems. The more autonomous decision-making skills and capabilities of the managers, the more stable control will be achieved in the organization. According to the findings of the research, it is seen that the organizational environment that enables easy decision-making caused by manager autonomy strengthens the position of managers to have strategic control. In this case, it can be said that the strategic planning performance also strengthens the strategic control situation and shows that positive management decisions lead to the formation of a positive organizational climate. The research results are important in revealing that the manager's autonomous decision-making will lead to control in the organization, and ensuring strategic control will increase the organization's strategically planned performance. Developing a positive and determined management structure will ensure a stable performance and functioning in the organization while at the same time ensuring that employees trust the 
manager. On the other hand, while managerial autonomy and strategic control enable employees to trust managers, they may also cause positive psychological perceptions.

The literature shows a common view that these variables are positive organizational situations in research on manager autonomy, strategic planning performance, and strategic control. In this context, strategic control and manager autonomy studies were generally associated with organizational policy and associated with organizational policy's strategic planning performance (Elbanna, 2016; Karacaoğlu and Saydam, 2020; Saydam, 2020). According to the data obtained from 175 four and five-star hotels in the Gulf Cooperation Council (GCC) countries, Elbanna (2016) determined that the combination of high levels of autonomy and low level of control negatively affected the effectiveness of strategic planning by increasing organizational tensions. In the first hypothesis of the study, manager autonomy's positive effect on strategic control was found ( $\mathrm{p}<0.001$ ). In the second hypothesis, the positive effect of strategic planning performance on strategic control was determined $(\mathrm{p}<0.001)$. The last hypothesis determined that strategic planning performance has no moderator effect on the interaction between manager autonomy and strategic control $(p=0.696>0.001)$. Since there is no similar research model in the literature to compare these findings, the obtained findings could not be discussed in the light of the relevant literature. Findings and research models obtained from this aspect constitute the original aspect of the study.

This research is limited to examining whether strategic planning performance has a moderator function in the interaction between manager autonomy and strategic control. The research is quantitative research limited to business executives operating in Konya Organized Industrial Zone. The research can be repeated in different samples with different leadership behaviors and different strategic situations. The research can also examine whether the strategic planning performance functions as a mediator variable in the relationship established. It can be repeated with different samples with qualitative and mixed-method researches to understand the research subject better.

\section{REFERENCES}

Abas, Z. ve Yaacob, Z. (2006). Exploring the relationships between total quality management (TQM), strategic control systems (SCS) and organizational performance (OP) using a SEM framework. Journal of American Academy of Business, 9(2), 161-166.

Acar, E. (2007). Yarı resmi bir örgütte stratejik planlama uygulamast: Aydın Ticaret Odası örneği. Adnan Menderes Üniversitesi, Sosyal Bilimler Enstitüsü Yükseklisans Tezi.

Adiguzel, Z. (2020). Evaluating the Impact of Strategic Management and Strategic Thinking on Performance in the Public Health Sector. In Multidimensional Perspectives and Global Analysis of Universal Health Coverage (pp. 231-265). IGI Global.

AlQershi, N. (2021). Strategic thinking, strategic planning, strategic innovation and the performance of SMEs: The mediating role of human capital. Management Science Letters, 11(3), 1003-1012.

Andersen, T. J. ve Nielsen, B. B. (2009). Adaptive strategy making: The effects of emergent and intended strategy modes. European Management Review, 6(2), 94-106. 
Bach, T. (2010). Policy and management autonomy of federal agencies in Germany. Governance of Public Sector Organizations (pp. 89-110): Springer.

Bakker, A. B., Demerouti, E. ve Verbeke, W. (2004). Using the job demands-resources model to predict burnout and performance. Human Resource Management: Published in Cooperation with the School of Business Administration, The University of Michigan and in alliance with the Society of Human Resources Management, 43(1), 83-104.

Bell, D. A. (1976). Serving two masters: Integration ideals and client interests in school desegregation litigation. The Yale Law Journal, 85(4), 470-516.

Berry, A. J., Coad, A. F., Harris, E. P., Otley, D. T. ve Stringer, C. (2009). Emerging themes in management control: A review of recent literature. The British Accounting Review, 41(1), $2-20$.

Bowman, C. ve Asch, D. (1992). Strategic Management, McMillan Edu. Ltd., Newyork. .

Bryson, J. M. (2004). Strategic Planning for Public and Non-Profit Organizations: A Guide. San Francisco, CA: Josey-Bass.

Çukurçayır, M. A. ve Eroğlu, H. T. (2005). Yerel Yönetimler ve Performans Denetimi, Yerel Yönetimler Üzerine Güncel Yazılar-1. Nobel Yayınc1lı, Ankara.

Drafke, M. W. ve Kossen, S. (1998). The human side of organizations: Addison-Wesley Reading, MA.

Edwards, R. R. ve LaFief, W. C. (2004). Strategic Control Will Help Small Business Survive. In: Erişim.

Ekber, Ş. ve Mirzayeva, G. (2016). Motivasyon Yönümlü Performans Değerlendirme-Örnek Olay Çalişmasi. Elektronik Mesleki Gelişim ve Araştırmalar Dergisi, 4(1).

Elbanna, S. (2013). Processes and impacts of strategic management: Evidence from the public sector in the United Arab Emirates. International Journal of Public Administration, 36(6), 426-439.

Elbanna, S. (2016). Managers' autonomy, strategic control, organizational politics and strategic planning effectiveness: An empirical investigation into missing links in the hotel sector. Tourism Management, 52, 210-220.

Ferris, G. R., Fedor, D. B., Chachere, J. G. ve Pondy, L. R. (1989). Myths and politics in organizational contexts. Group \& Organization Studies, 14(1), 83-103.

Fornell, C. ve Larcker, D. F. (1981). Evaluating structural equation models with unobservable variables and measurement error. Journal of marketing research, 18(1), 39-50.

Goold, M. ve Quinn, J. J. (1990). The paradox of strategic controls. Strategic management journal, 11(1), 43-57.

Gül, C. (2013). Bankacılık Sektöründe Görev Performans ve Bağlamsal Performans: Yalova İlinde Bir Araştırma. Tezi, Yalova Üniversitesi Sosyal Bilimler Enstitüsü Çalışma Ekonomisi ve Endüstri İlişkileri Enstitü Bilim Dalı.

Gümüş, M. (1995). Yönetimde başarı için altın kurallar: Alfa. 
Hair, J. F., Black, W. C., Babin, B. J., Anderson, R. E. ve Tatham, R. (2006). Multivariate data analysis . Uppersaddle River. In: NJ: Pearson Prentice Hall.

Hastürk, M. ve Kontrolörü, M. (2006). Stratejik Planlama Ve Performans Esasli Bütçeleme.

Hicks, H. G. ve Gullett, C. R. (1981). Management, McGraw Hill, Inc.

Hughes, M. ve Morgan, R. E. (2007). Deconstructing the relationship between entrepreneurial orientation and business performance at the embryonic stage of firm growth. Industrial marketing management, 36(5), 651-661.

Karacaoğlu, K. ve Saydam, F. (2020). Otel İşletmelerinde yönetici özerkliği, stratejik kontrol, örgütsel politika ve stratejik planlama performansi İlişkisi üzerine bir araştirma: Antalya örneği. Mehmet Akif Ersoy Üniversitesi İktisadi ve İdari Bilimler Fakültesi Dergisi, 7(3), 611-630.

Karakaya, A. ve Akbulut, H. (2013). İşletmelerde Sorumluluk Merkezlerinin Stratejik Kontrol Ve Muhasebe Sistemi Açısından Analizi. International Journal of Economic \& Social Research, 9(1).

Karasek, R. (1990). Healthy work. Stress, productivity, and the reconstruction of working life.

Keyes, C. L., Shmotkin, D. ve Ryff, C. D. (2002). Optimizing well-being: the empirical encounter of two traditions. Journal of personality and social psychology, 82(6), 1007.

Khan, M. ve Khalique, M. (2014). Strategic planning and reality of external environment of organizations in contemporary business environments. Business Management and Strategy, 5(2).

Kline, P. (2014). An easy guide to factor analysis: Routledge.

Kuye, O. ve Oghojafor, B. (2011). Strategic Control and Corporate Performance in the Manufacturing Industry. European Journal of Social Sciences - Volume 22, Number 2.

MacKenzie, S. B. ve Podsakoff, P. M. (2012). Common method bias in marketing: Causes, mechanisms, and procedural remedies. Journal of retailing, 88(4), 542-555.

Merchant, K. A. (1988). Progressing toward a theory of marketing control: a comment. Journal of Marketing, 52(3), 40-44.

Miller, D. (1996). Configurations revisited. Strategic management journal, 17(7), 505-512.

Nixon, B. ve Burns, J. (2012). The paradox of strategic management accounting. Management Accounting Research, 23(4), 229-244.

Otley, D., Broadbent, J. ve Berry, A. (1995). Research in management control: an overview of its development. British Journal of management, 6, S31-S44.

Pearce, J. A. ve David, F. (1987). Corporate mission statements: The bottom line. Academy of Management Perspectives, 1(2), 109-115.

Phillips, P. A. ve Moutinho, L. (2000). The strategic planning index: A tool for measuring strategic planning effectiveness. Journal of travel research, 38(4), 369-379.

Phillips, P. A. (2003). Special issue on the dynamics of strategy. Journal of Business Research, 56(2), 93-94. 
Rodoplu, D. (2004). Stratejik yönetim düzeyinde yetki devri. Review of Social, Economic \& Business Studies, 3(4), 251-273.

Saydam, F. (2020). Otel işletmelerinde yönetici özerkliği, stratejik kontrol, örgütsel politika ve stratejik planlama performansı üzerine bir araştırma: Antalya örneği. (Doctorate Thesis),

Shrivastava, P. ve Grant, J. H. (1985). Empirically derived models of strategic decision-making processes. Strategic management journal, 6(2), 97-113.

Stamps, P. ve Piedmont, E. (1986). Work satisfaction: An index for measurement. Ann Arbor, MI: Nurses and Health Administration Press.

Sütçü, O. (2008). Stratejik liderlik. Sütçü İmam Üniversitesi Sosyal Bilimler Enstitüsü Işletme Ana Bilim Dalı. Yayımlanmamış Yüksek Lisans Projesi. Kahramanmaraş. ss, 60.

Titus, V., McDougall, P. ve Slevin, D. (2010). Utilizing strategy formation mode and strategic learning to traverse various landscapes. Paper presented at the Academy of Management Conference, Montreal, Canada.

Tutar, H. ve Erdem, A. T. (2020). Örnekleriyle Bilimsel Araştirma Yöntemleri ve - SPSS Uygulamaları. Seçkin Yayncılık.

Ülgen, H. ve Mirze, S. K. (2013). İşletmelerde stratejik yönetim: Beta Basım Yayın. In: İstanbul.

Weihrich, H. ve Koontz, H. (2005). Management: A global perspective: Tata McGraw-Hill.

Yam, R. C., Guan, J. C., Pun, K. F. ve Tang, E. P. (2004). An audit of technological innovation capabilities in Chinese firms: some empirical findings in Beijing, China. Research policy, 33(8), 1123-1140. 